\title{
Selection of half-sib families of creole melon (Cucumis melo L.) on the Ecuadorian coast
}

\section{Evaluación de familias de medios hermanos de melón criollo (Cucumis melo L.) en la costa ecuatoriana}
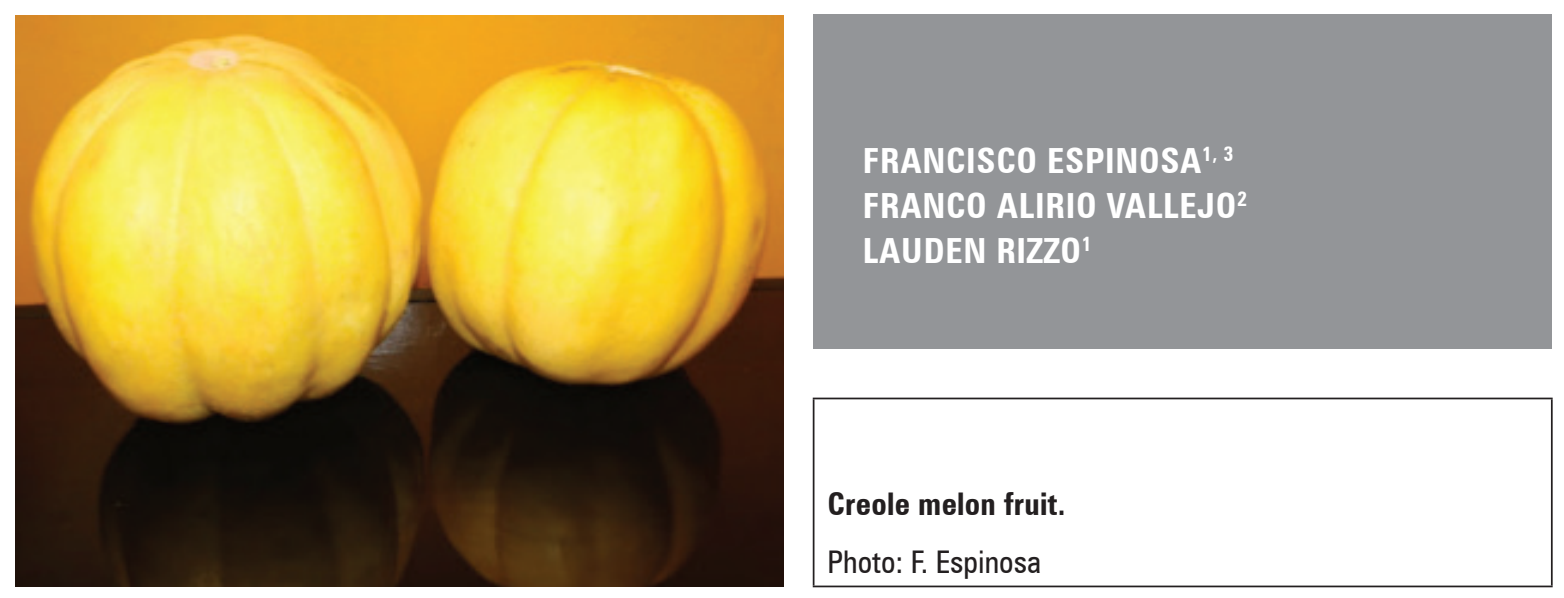

\begin{abstract}
The creole melon cantaloupe is a horticultural species, whose fruits are used for human nutrition. However, no research has been reported on their genetic variability for starting breeding processes. The objective of this study was to take advantage of the variability of creole melons for genetic improvement. 20 creole melon half-sib families were selected and evaluated for production characteristics and fruit quality in order to obtain improved populations. The study was carried out in Palenque canton, Ecuador. Seeds from 20 half-sib families were used, arranged in a randomized complete block design with three replications. The differences between the families were significant for all the studied characteristics. Family 93 presented higher averages for fruit weight, fruit diameter and production (per hectare), and family 196 did so for soluble solids. The phenotypic correlations were positive and significant between the fruit weight and fruit diameter, fruit length, pulp thickness, fruit cavity, soluble solids and production. The coefficients of genetic variation, in general, were lower than the coefficients of environmental variation. The estimates of heritability broadly had a moderate magnitude (30-60\%) for the 10 evaluated characteristics, and the magnitude of the expected genetic progress was low $(<10 \%)$ for the fruit weight, production, and soluble solids, so the selection for high production should focus on fruit weight and soluble solids.
\end{abstract}

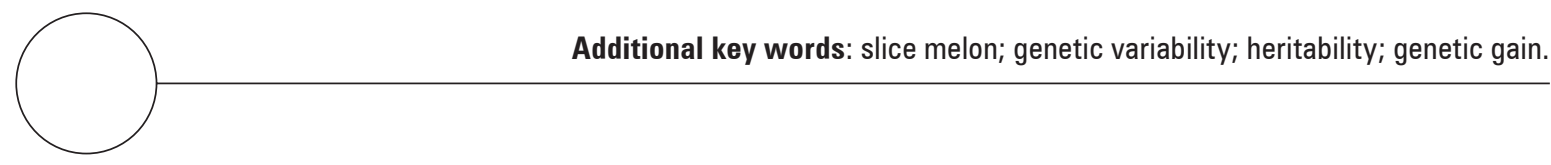

\footnotetext{
1 Universidad Técnica Estatal de Quevedo, Distance Studies Unit, Quevedo (Ecuador). ORCID Espinosa, F.: 0000-00030161-6483; ORCID Rizzo, L.: 0000-0002-0732-7036

2 Universidad Nacional de Colombia, Sede Palmira, Palmira (Colombia). ORCID Vallejo, F.A.: 0000-0002-2739-0745

3 Corresponding author. josfespinosacar@unal.edu.co
} 


\section{RESUMEN}

El melón criollo de tajada cantalupo es una especie hortícola, cuyos frutos son utilizados en la alimentación humana. Sin embargo, no se han reportado investigaciones de su variabilidad genética para iniciar procesos de mejoramiento. El objetivo de esta investigación fue aprovechar la variabilidad de los melones criollos para mejorarlos genéticamente, mediante selección. Se seleccionaron y evaluaron 20 familias de medios hermanos de melón criollo de tajada por características de producción y calidad del fruto, con el fin de obtener poblaciones mejoradas. El estudio se realizó en el cantón Palenque, Ecuador. Se utilizó semilla de 20 familias de medios hermanos, dispuestas en un diseño de bloques completos al azar con tres repeticiones. Las diferencias entre familias fueron significativas para todos los caracteres estudiados. La familia 93 presentó mayores promedios para peso de fruto, diámetro de fruto y producción (por hectárea) y la familia 196 para sólidos solubles. Las correlaciones fenotípicas fueron positivas y significativas entre el peso de fruto y el diámetro de fruto, longitud del fruto, espesor de la pulpa, cavidad del fruto, sólidos solubles y producción. Los coeficientes de variación genética, en general, fueron menores que los coeficientes de variación ambiental. Las estimaciones de heredabilidad en sentido amplio fueron de magnitud moderada (30-60\%) para los 10 caracteres evaluados y la magnitud del progreso genético esperado fue baja $(<10 \%)$ para peso de fruto, producción, y sólidos solubles, por lo que se considera que la selección para melones de alta producción debe enfocarse en peso del fruto y sólidos solubles.

Palabras clave adicionales: melón de tajada; variabilidad genética; heredabilidad; ganancia genética.

Received for publication: 08-06-2018 Accepted for publication: 31-07-2019

INTRODUCTION

The genus Cucumis, which includes melon (Cucumis melo L.), has numerous wild species in Africa, which is its origin (Sebastian et al., 2010), from where it dispersed to the rest of the world, and, nowadays, it is cultivated under tropical and subtropical climatic conditions (Reddy et al., 2013a). According to the FAO (2014), melons and watermelons, from the commercial point of view, are horticultural crops because they are temporary crops.

In $2010,1,074,558$ ha of melon were grown worldwide. Production in that year reached 25.0 million metric tons, with China being the largest producer, accounting for $45 \%$ of global production (MongePérez, 2013). The data published by FAOSTAT, the statistical agency of the Food and Agriculture Organization of the United Nations (FAO), for 2014 indicated that global melon production was 29.62633 billion tons, over an area of 1,189,565 ha, with an average yield of $2.49 \mathrm{~kg} \mathrm{~m}^{2}$. The data from (FAO, 2018), based on the imputation methodology, indicated that, in Ecuador, 2,036 ha were cultivated in 2016, with an average yield of $2.43 \mathrm{~kg} \mathrm{~m}^{2}$, which represented a total production of 49,201 t. The cultivated area had a high percentage of hybrid melon seeds from transnational companies.

On the Ecuadorian coast, there are creole melons, grown by small farmers, which are highly appreciated by local consumers because of their aroma and flavor. The Ecuadorian creole melon is a little explored cultivar. This melon exhibits a wide phenotypic diversity for fruit traits, including fruit ripening, fruit shape, size, flesh color, texture, sweetness and aroma (Latrasse et al., 2017). Preliminary tests showed that the yields of these creole varieties were below $4 \mathrm{t}$ ha, much lower than the production of imported hybrids that are commercially cultivated. This is possibly due to the poor quality of the creole variety seeds, which are obtained from the previous harvest or purchased in the local market (UPOV, 2008).

In the provinces of Manabí, Los Ríos and Guayas, creole melon crops have been identified, within which there is the melon known as 'Slice Melon' (Fig. 1), which is characterized by having a large fruit that can reach weigh more than $4 \mathrm{~kg}$, with a rounded, oval or flattened shape, thick, smooth bark 
and segmentations or grooves arranged as meridians (apostille), pale yellow to intense yellow color, and white, pink or orange broad pulp, with a characteristic fragrant odor and sweet flavor, possibly belonging to C. melo var. Naud cantaloupensis, which, according to (Guis et al., 1998), have fruits with a round shape, medium size, smooth surface, marked ribs, orange flesh, aromatic and sweet flavor. The intraspecific classification of $C$. melo has been reviewed several times, the most recent performed by Pitrat, in 2008, included within this species are two subspecies, melo and agrestis and 15 varieties: Cantalupensis and inodorus varieties have greater commercial interest (Pavan et al., 2017) and are the most cultivated in the world (Abraham et al., 2018).

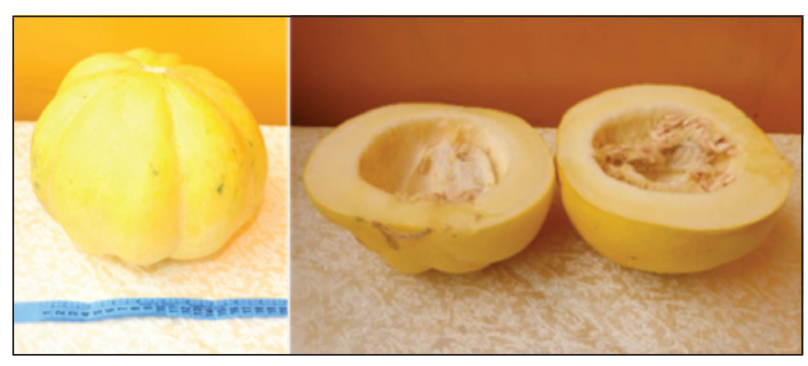

Figure 1. Creole melon fruit (photo: F. Espinosa).

The use of creole melon varieties depends on the availability of seeds and access for farmers to other production resources such as land, water, fertilizers and work capacity (Chacón and García, 2016). To maintain and improve the competitiveness of the creole melon, it is necessary to promote innovation in varieties and crop management technologies. New varietal options that offer better productive and organoleptic characteristics must be sought (Monge-Pérez, 2013). Previous research showed the productive potential of the creole melon, which creates the need to identify the ability to achieve advances in the production and organoleptic quality of the sliced melons with a formal procedure. The aim of this research was to evaluate 20 half-sib families of slice creole melon (Cucumis melo L.) on the Ecuadorian coast with characteristics of production and quality of the fruits.

\section{MATERIALS AND METHODS}

This study was conducted in Palenque, Provincia de Los Ríos, Ecuador, located at latitude -638455 and longitude -9841885 . The main climate characteristics are presented in (Tab. 1).
Table 1. Climatological characteristics in Palenque, Provincia de Los Ríos, Ecuador. 2018.

\begin{tabular}{|l|c|}
\hline \multicolumn{1}{|c|}{ Parameters } & Annual average \\
\hline Temperature $\left({ }^{\circ} \mathrm{C}\right)$ & $24-25$ \\
\hline Relative humidity (\%) & $75-80$ \\
\hline Annual heliofania (hours light) & $1,011.9$ \\
\hline Precipitation (mm year ${ }^{1}$ ) & $1,500-2,000$ \\
\hline Ecological zone & Tropical dry forest \\
\hline
\end{tabular}

Source: GADCO (2014), INAMHI (2016).

From a massal population that represented the creole melon collection, made between August 2015 and April 2016, on the Ecuadorian coast, 20 half- sib families were selected for further evaluation. Seeds from the massal population were used as a control treatment.

The 20 half-sib families and the control treatment were evaluated in a randomized complete block design with three repetitions. In each repetition, the families were located randomly. The experiment units were linear plots with 5 plants, the net plot had 3 plants, with $3 \mathrm{~m}$ between rows and $1.50 \mathrm{~m}$ between plants, according to the traditional form of cultivation of creole melons; and the population density was 2,222 plants/ha.

In each plant, characteristics related to the commercial fruit were evaluated: fruit weight (FW) using an electronic scale Jadever JWP with a capacity of $6,000.0 \pm 0.1 \mathrm{~g}$, fruit diameter (FD), fruit length (FL), pulp thickness (PT) (Wang et al., 2016), bark thickness (BT) and fruit cavity (FC) (Aragão et al., 2015) measured with a digital electronic caliper brand Uberman, pulp firmness (PF) quantified with a fruit hardness meter model FHT-804 with a capacity of $24 \pm 0.1 \mathrm{~kg} \mathrm{~cm}^{-2}$ (Monge, 2016), (SS) soluble solids ('Brix) measured with a RHB-50ATC refractometer, scale of $0.0-50.0 \pm 0.2 \%$ (Aragão et al., 2015), pulp acidity (PA) quantified with a digital $\mathrm{pH}$ electronic meter Biocharge ATC and production per hectare calculated with the average weight of the fruits in the population density of 2,222 plants/ha.

Each characteristic was submitted to an analysis of variance under the experiment block design, randomly with three repetitions. In the case of significant differences between the families, the comparison of means was made with the Tukey test $(P \leq 0.05)$ (Abraham et al., 2018). A correlation analysis was carried 
out for the evaluated characteristics. The results were processed with the statistical software SAS 9.4.

The environmental (1), genetic (2) and phenotypic (3) variances were determined using the analysis of variance, according to the equations below:

Environmental variance $\left(\sigma_{\mathrm{E}}^{2}\right)=\mathrm{CMe}$

Genetic variance $\left(\sigma_{\mathrm{G}}^{2}\right)=\frac{C M f-C M e}{r}$

Phenotypic variance $\left(\sigma_{\mathrm{P}}^{2}\right)=\sigma_{\mathrm{G}}^{2}+\sigma_{\mathrm{E}}^{2}$

where CMf is mean square of the families, $C M e$ is mean square of the experimental error, and $r$ is number of repetitions (Pistorale et al., 2008).

The coefficients of genetic (4) and environmental (5) variation were calculated according to:

Genetic variation coefficient

$$
\mathrm{GVC}=\frac{\sqrt{\sigma^{2} \mathrm{G}}}{\overline{\mathrm{X}}} \times 100
$$

Environmental variation coefficient

$$
\mathrm{EVC}=\frac{\sqrt{\sigma^{2} \mathrm{E}}}{\overline{\mathrm{X}}} \times 100
$$

Broad heritability (6) for each variable was estimated classically, as described below:

Broad heritability $\mathrm{h}_{\mathrm{A}}^{2}=\left(\sigma_{\mathrm{C}}^{2} / \sigma_{\mathrm{P}}^{2}\right) \times 100$

Generic progress expected with the classic formula: $\Delta \mathrm{g}=\mathrm{ds} \times \mathrm{h}_{\mathrm{A}}^{2}$, where $\mathrm{ds}=$ differential of selection.

The values of the phenotypic variation coefficients (PVC), genotypic variation (GVC) and genetic progress were low $(<10 \%)$, moderate $(10-20 \%)$ and high $(>20 \%)$. The heritability values were low $(<30 \%)$, moderate $(30-60 \%)$ and high $(>60 \%)$, as used by (Reddy et al., 2013a).

The establishment of the plots was done with direct sowing, depositing a seed previously treated with aluminum tris-o-ethylphosphonato per site. The crop received fertilization at $150 \mathrm{~kg} \mathrm{ha}^{-1}$ of the formula 8-20-20 plus $100 \mathrm{~kg} \mathrm{ha}^{-1}$ of urea $\mathrm{N}$ at $46 \%$, with two applications. Pre-emergence weed control was carried out with an application of glyphosate, along with a post-emergence application of paraquat dichloride $276 \mathrm{~g} \mathrm{~L}^{-1}$ between the plants and an application of haloxyfop-R-methyl ester, 108 g. Additionally, two manual cleansings were performed. The pest control, mainly trips (Frankliniella occidentalis) and aphids (Aphididae), was carried out with six rotating applications of abamectin, imidacloprid and triflumuron. The control of fungal diseases was carried out in a preventive manner with eight rotating applications of fosetil aluminum and fludioxonil $2.5 \mathrm{~g}+$ metalaxil-M $1.0 \mathrm{~g}$. The soil remained at field capacity with a drip irrigation system installed with drippers that supplied water at a rate of $2 \mathrm{~L} \mathrm{~h}^{-1}$. Fruit harvesting began $93 \mathrm{~d}$ after sowing, when the fruits had the characteristic yellow color of maturity.

\section{RESULTS AND DISCUSSION}

The mean squares of the 10 characteristics evaluated in the 20 half-sib families of creole melon (Tab. 2) presented statistically significant differences $(P \leq 0.05)$ for fruit cavity (FC) and highly statistically significant $(P \leq 0.01)$ differences for the other nine characteristics, showing high variability between the melon families. The coefficient of variation (CV) was higher than $30 \%$ for fruit weight (FW), pulp firmness (PF) and production; the other evaluated characteristics had a (CV) less than 23\%. These results indicated that the creole melon massal population contained broad reserves of genetic variation and adaptation to different environmental conditions (Eguiarte et al., 2013), in agreement with the results obtained by Reddy et al. (2013a), who stated that the highly significant differences between the genotypes indicated the presence of a sufficient amount of variability in the germplasm, facilitating selection possibilities for modifying the studied characteristics.

The averages, maximum, and minimum values presented significant difference for the characteristics of the 20 melon half-sib families (Tab. 3). Family 93 showed the highest average fruit weight $(5,201.80$ g), fruit diameter $(179.59 \mathrm{~mm})$ and production $\left(11,560.00 \mathrm{~kg} \mathrm{ha}^{-1}\right)$, family 176 showed the highest average for fruit length $(213.78 \mathrm{~mm})$, family $117 \mathrm{did}$ so for the thickness of the pulp $(38.62 \mathrm{~mm})$, family 21 did so for the thickness of the bark $(1.07 \mathrm{~mm})$, family 68 did so for fruit cavity $(103.60 \mathrm{~mm})$, family 47 did so for pulp firmness (5.11), (the minimum acceptable firmness is $3.1 \mathrm{~kg} \mathrm{~cm}^{2}$ for Cantaloupe melon and Orange Flesh (Monge, 2016)), family 123 did so for acidity of pulp (7.04) and family 196 (8.44) did so for soluble solids. These values were higher than those reported by (Reddy et al., 2013a) in his research 
on 35 lines of cantaloupe cross-linked melon, who obtained an average fruit weight of $(\mathrm{g}) 416.57 \pm 17.94$, fruit diameter of $(\mathrm{cm}) 8.56 \pm 0.38$, fruit length of (cm) 10.70 \pm 0.48 , pulp thickness of $(\mathrm{cm}) 1.58 \pm 0.11$, bark thickness of $(\mathrm{mm}) 1.70 \pm 0.14$, fruit cavity length of $(\mathrm{cm}) 6.26 \pm 0.33$, fruit cavity width of $(\mathrm{cm})$ $4.65 \pm 0.25$, total soluble solids of ( $\left.{ }^{\circ} \mathrm{Brix}\right) 6.70 \pm 0.15$ and fruit production of $(\mathrm{kg} / \mathrm{plant}) 1.16 \pm 0.15$. Monge

Table 2. Mean squares of the analysis of variance and coefficients of variation for the 10 fruit characteristics of the creole melon (Cucumis melo L.) cantaloupe. Palenque, Provincia de Los Ríos, Ecuador. 2018.

\begin{tabular}{|c|c|c|c|c|c|c|}
\hline Source & DF & FW $(g)$ & $\mathrm{FD}(\mathrm{mm})$ & $\mathrm{FL}(\mathrm{mm})$ & $\mathrm{FT}(\mathrm{mm})$ & BT (mm) \\
\hline Blocks & 2 & $31473929.10^{* *}$ & $9429.66^{* *}$ & $10952.60^{* *}$ & $63.64^{\mathrm{NS}}$ & $0.03^{\mathrm{NS}}$ \\
\hline Families & 20 & $6037165.10^{* *}$ & $796.04^{* *}$ & $2257.00^{* *}$ & $91.86^{* *}$ & $0.09^{* *}$ \\
\hline Blocks $\times$ Family & 40 & 1809207 & 352.26 & 511.15 & 0.04 & 0.04 \\
\hline CV & & 39.51 & 11.82 & 13.28 & 16.15 & 22.87 \\
\hline Source & DF & $\mathrm{FC}(\mathrm{mm})$ & $\mathrm{PF}\left(\mathrm{kg} \mathrm{cm}^{2}\right)$ & $\mathrm{PA}(\mathrm{pH})$ & SS ( ${ }^{\circ}$ Brix) & $P\left(\mathrm{~kg} \mathrm{ha}^{-1}\right)$ \\
\hline Blocks & 2 & $3011.42^{* *}$ & $2.61^{\mathrm{NS}}$ & $0.30^{\mathrm{NS}}$ & $10.24^{* *}$ & $155426521.00 * *$ \\
\hline Families & 20 & $422.09 *$ & $3.73^{* *}$ & $0.43^{* *}$ & $2.91 * *$ & $29813106.90^{* *}$ \\
\hline Blocks $\times$ Family & 40 & 228.09 & 1.72 & 0.14 & 0.80 & 8934337.00 \\
\hline CV & & 16.71 & 32.69 & 5.63 & 12.39 & 39.51 \\
\hline
\end{tabular}

FW, fruit weight; FD, fruit diameter; FL, fruit length; PT, pulp thickness; BT, bark thickness; FC, fruit cavity; PF, pulp firmness; PA, pulp acidity; SS, soluble solids ('Brix): $P$, production $\left(\mathrm{kg} \mathrm{ha}^{-1}\right)$. DF, degrees of freedom; * * significance level $P \leq 0.01$; ${ }^{*}$ significance level $P \leq 0.05$ of probability; Ns. non-significant.

Table 3. Averages, maximum values, minimum values and significant minimum difference for the characteristics of 20 half-sib families of creole melon (Cucumis melo L.) cantaloupe. Palenque, Provincia de Los Ríos, Ecuador. 2018.

\begin{tabular}{|c|c|c|c|c|c|c|c|c|c|c|}
\hline Families & $\mathrm{FW}(\mathrm{g})$ & $\mathrm{FD}(\mathrm{mm})$ & $\mathrm{FL}(\mathrm{mm})$ & $\mathrm{FT}(\mathrm{mm})$ & $\mathrm{RT}(\mathrm{mm})$ & $\mathrm{FC}(\mathrm{mm})$ & $\operatorname{PF}\left(\mathrm{kg} \mathrm{cm}^{-2}\right)$ & $\mathrm{PA}(\mathrm{pH})$ & SS ( ${ }^{\circ}$ Brix) & $P\left(\mathrm{~kg} \mathrm{ha}^{-1}\right)$ \\
\hline 21 & 2662.90 & 167.03 & 198.17 & 35.02 & 1.07 & 98.07 & 4.64 & 6.67 & 7.78 & 5918.00 \\
\hline 43 & 2900.80 & 153.52 & 179.67 & 36.01 & 0.78 & 91.59 & 3.96 & 6.69 & 6.89 & 6446.00 \\
\hline 44 & 3588.20 & 163.02 & 174.41 & 35.68 & 0.81 & 88.15 & 4.33 & 6.32 & 7.11 & 7974.00 \\
\hline 47 & 3205.00 & 158.65 & 169.12 & 32.89 & 0.78 & 89.46 & 5.11 & 6.39 & 7.56 & 7122.00 \\
\hline 61 & 3864.80 & 165.20 & 175.33 & 37.40 & 0.81 & 96.89 & 4.34 & 6.71 & 7.78 & 8588.00 \\
\hline 68 & 4743.70 & 165.67 & 167.17 & 35.03 & 0.73 & 103.60 & 3.57 & 6.43 & 6.89 & 10541.00 \\
\hline 86 & 2745.30 & 150.78 & 155.12 & 30.29 & 0.84 & 78.23 & 3.37 & 6.88 & 7.33 & 6101.00 \\
\hline 89 & 4087.30 & 154.64 & 173.50 & 33.80 & 0.73 & 86.95 & 4.55 & 6.56 & 7.44 & 9083.00 \\
\hline 93 & 5201.80 & 179.59 & 189.57 & 38.49 & 0.82 & 94.77 & 3.49 & 6.85 & 7.78 & 11560.00 \\
\hline 97 & 3740.70 & 150.50 & 161.59 & 35.91 & 0.82 & 83.77 & 3.77 & 6.15 & 6.67 & 8313.00 \\
\hline 109 & 2516.30 & 150.75 & 161.04 & 30.32 & 0.97 & 86.30 & 3.88 & 6.55 & 7.11 & 5592.00 \\
\hline 110 & 3160.70 & 151.67 & 157.35 & 33.43 & 0.64 & 87.71 & 3.76 & 6.74 & 6.67 & 7024.00 \\
\hline 117 & 3891.20 & 171.70 & 167.33 & 38.62 & 0.80 & 99.52 & 4.36 & 6.49 & 7.78 & 8647.00 \\
\hline 123 & 3147.80 & 168.03 & 178.89 & 36.30 & 0.84 & 84.36 & 4.27 & 7.04 & 7.22 & 6995.00 \\
\hline 138 & 3106.10 & 162.43 & 150.93 & 34.98 & 0.84 & 93.86 & 4.50 & 6.62 & 6.89 & 6902.00 \\
\hline 140 & 4454.00 & 156.67 & 163.00 & 26.52 & 0.92 & 84.81 & 2.46 & 6.47 & 7.11 & 9898.00 \\
\hline 149 & 2421.90 & 159.29 & 172.11 & 32.46 & 0.87 & 86.49 & 4.57 & 6.59 & 6.78 & 5382.00 \\
\hline 176 & 2874.70 & 163.97 & 213.78 & 35.07 & 0.85 & 97.59 & 2.83 & 6.61 & 7.89 & 6388.00 \\
\hline 177 & 3560.80 & 154.75 & 154.55 & 32.31 & 0.90 & 93.63 & 4.75 & 6.47 & 7.11 & 7913.00 \\
\hline 196 & 3794.80 & 149.68 & 164.66 & 28.74 & 0.99 & 93.85 & 3.98 & 6.99 & 8.44 & 8433.00 \\
\hline testigo & 1815.50 & 137.05 & 148.57 & 30.21 & 0.69 & 77.90 & 3.68 & 6.74 & 5.83 & 4035.00 \\
\hline Average & 3404.01 & 158.79 & 170.28 & 33.79 & 0.83 & 90.36 & 4.01 & 6.62 & 7.24 & 7564.52 \\
\hline Maximum & 5201.8 & 179.59 & 213.78 & 38.62 & 1.07 & 103.6 & 5.11 & 7.04 & 8.44 & 11560.00 \\
\hline Minimum & 1815.5 & 137.05 & 148.57 & 26.52 & 0.64 & 77.9 & 2.46 & 6.15 & 5.83 & 4035.00 \\
\hline LSD & 2300.7 & 32.1 & 38.67 & 9.33 & 0.33 & 25.83 & 2.24 & 0.64 & 1.53 & 5112.7 \\
\hline
\end{tabular}

FW, fruit weight; FD, fruit diameter; FL, fruit length; PT, pulp thickness; RT, rind thickness; FC, fruit cavity; PF, pulp firmness; PA, pulp acidity; SS, soluble solids ('Brix); P, production $\left(\mathrm{kg} \mathrm{ha}^{-1}\right)$. LSD = Least significant difference Tukey $(P \leq 0.05)$. 
(2016) evaluated 70 greenhouse melon genotypes and found inferior results for fruit weight and pulp firmness and higher results for percentage of total soluble solids; in addition, the characteristics showed wide variability among the genotypes in terms of average fruit weight (268.7-1279.4 g), production per area (0$\left.70.85 \mathrm{t} \mathrm{ha}^{-1}\right)$, fruit firmness $\left(0.5-4.8 \mathrm{~kg} \mathrm{~cm}^{-2}\right)$ and percentage of total soluble solids (9.9-17. $\left.1^{\circ} \mathrm{Brix}\right)$.

The correlation coefficients between the characteristics in the 20-half-sib-families of melon (Tab. 4) showed positive significant phenotypic associations between the fruit weight (FW) with the fruit diameter (FD), fruit length (FL), pulp thickness (PT), fruit cavity (FC), soluble solids (SS, ${ }^{\circ}$ Brix) and production $\left(\mathrm{kg} \mathrm{ha} \mathrm{a}^{-1}\right)$, indicating that the selection for a greater fruit weight would lead to an increase in the thickness of the pulp, soluble solids and production per hectare. A negative, non-significant correlation was found between the fruit weight (FW) and the rind thickness (RT), pulp acidity (PA) and pulp firmness $(\mathrm{PF})$. There were significant and positive phenotypic correlations between the (SS) soluble solids ( ${ }^{\circ} \mathrm{Brix}$ ) and the fruit diameter (FD), fruit length (FL), pulp thickness (PT), fruit cavity (FC) and production (kg $\mathrm{ha}^{-1}$ ). All significant correlations were positive except for the correlation between the pulp acidity (PA) and the pulp firmness $(\mathrm{PF})$ and production $\left(\mathrm{kg} \mathrm{ha}^{-1}\right)$. The correlation can be attributed to the presence of pleiotropic effects of the genes, physiological relationship and development, environmental effect or a combination of all the above (Reddy et al., 2013b). The correlation coefficient associations, of great or little value, could be found for an improvement program through selection.

The values of the coefficients of genotypic variation (GVC) for the characteristics evaluated in the 20 halfsib families, in general, were lower than the values of the coefficients of environmental variation (EVC). The parameters of heritability $\left(\mathrm{h}^{2} \mathrm{~A}\right)$ were moderate, and the genetic advance $(\Delta \mathrm{g})$ had a low magnitude (Tab. 5).

For the fruit weight (FW), the (GVC) was $34.87 \%$, and the (EVC) was $39.51 \%$, indicating that both the genetic and environmental components had similar variations in the phenotypic manifestation of the characteristic. These results differ with that reported by Reddy et al. (2013b), who stated that the average fruit weight registered high EVC and GVC values, which indicated the presence of a high degree of variability and a better scope for the improvement of these characteristics through selection. The soluble solids (SS) presented a GVC equal to $11.57 \%$ and a EVC equal to $12.39 \%$, indicating little genetic and environmental variation in the expression of this characteristic. Reddy et al. (2013b) reported that the total soluble solids showed low to moderate EVC and GVC values, which indicated the presence of a high degree of variability and, therefore, a greater margin of selection. The production $\left(\mathrm{kg} \mathrm{ha}^{-1}\right)$ presented a GVC of $34.87 \%$ and a EVC of $39.50 \%$, indicating similar variations in the manifestation of this characteristic.

Table 4. Correlation coefficients ( $r$ ) among the characteristics evaluated in 20 half-sib families of creole melon (Cucumis melo L.) cantaloupe. Palenque, Provincia de Los Ríos, Ecuador. 2018.

\begin{tabular}{|c|c|c|c|c|c|c|c|c|c|}
\hline Characteristic & $\begin{array}{c}\text { FD } \\
(\mathrm{mm})\end{array}$ & $\begin{array}{c}\mathrm{FL} \\
(\mathrm{mm})\end{array}$ & $\begin{array}{c}\text { PT } \\
(\mathrm{mm})\end{array}$ & $\begin{array}{c}\text { BT } \\
(\mathrm{mm})\end{array}$ & $\begin{array}{c}\mathrm{FC} \\
(\mathrm{mm})\end{array}$ & $\begin{array}{c}\text { SS } \\
\text { ('Brix) }\end{array}$ & $\begin{array}{c}\mathrm{PA} \\
(\mathrm{pH})\end{array}$ & $\begin{array}{c}\mathrm{PF} \\
\left(\mathrm{kg} \mathrm{cm}^{-2}\right)\end{array}$ & $\begin{array}{c}P \\
\left(k g h a^{-1}\right)\end{array}$ \\
\hline FW (g) & $0.54^{* *}$ & $0.32 * *$ & $-0.04^{\mathrm{NS}}$ & $0.22^{* *}$ & $0.47^{* *}$ & $0.36^{* *}$ & $-0.12^{\mathrm{NS}}$ & $-0.12^{\mathrm{NS}}$ & $1.00^{* *}$ \\
\hline $\mathrm{FD}(\mathrm{mm})$ & & $0.64^{* *}$ & $0.02^{\mathrm{NS}}$ & $0.51^{* *}$ & $0.66^{* *}$ & $0.51^{* *}$ & $0.09^{\mathrm{NS}}$ & $0.09^{N S}$ & $0.556^{* *}$ \\
\hline $\mathrm{FL}(\mathrm{mm})$ & & & $0.15^{*}$ & $0.46^{* *}$ & $0.45^{* *}$ & $0.49^{* *}$ & $0.06^{\mathrm{NS}}$ & $0.08^{\mathrm{NS}}$ & $0.32^{* *}$ \\
\hline PT (mm) & & & & $-0.03^{\text {NS }}$ & $-0.02^{\text {NS }}$ & $0.11^{\mathrm{NS}}$ & $0.05^{\mathrm{NS}}$ & $0.07^{\mathrm{NS}}$ & $-0.04^{\mathrm{NS}}$ \\
\hline BT (mm) & & & & & $0.30^{* *}$ & $0.24^{* *}$ & $0.03^{\mathrm{NS}}$ & $0.09^{N S}$ & $0.23^{* *}$ \\
\hline $\mathrm{FC}(\mathrm{mm})$ & & & & & & $0.36^{* *}$ & $-0.13^{N S}$ & $0.18^{*}$ & $0.47^{* *}$ \\
\hline SS ('Brix) & & & & & & & $0.18^{\mathrm{NS}}$ & $0.12^{\mathrm{NS}}$ & $0.36^{* *}$ \\
\hline $\mathrm{PA}(\mathrm{pH})$ & & & & & & & & $-0.18^{*}$ & $-0.12^{* *}$ \\
\hline $\mathrm{PF}\left(\mathrm{kg} \mathrm{cm}^{-2}\right)$ & & & & & & & & & $-0.12^{\mathrm{NS}}$ \\
\hline
\end{tabular}

FW, fruit weight; FD, fruit diameter; FL, fruit length; PT, pulp thickness; BT, bark thickness; FC, fruit cavity; SS, soluble solids; PA, pulp acidity; PF, pulp firmness; P, production.

${ }^{* *}$ significance level $P \leq 0.01 ; *$ significance level $P \leq 0.05$ of probability; Ns: non-significant. 
Table 5. Averages, genetic variation coefficient, environmental variation coefficient, heritability in a broad sense and expected genetic progress (expressed in percentage) of the characteristics evaluated in $\mathbf{2 0}$ half-sib families of creole melon (Cucumis melo L.) cantaloupe. Palenque, Provincia de Los Ríos, Ecuador. 2018.

\begin{tabular}{|c|c|c|c|c|c|c|}
\hline Characters & Averages & $\begin{array}{l}\text { GVC } \\
(\%)\end{array}$ & $\begin{array}{l}\text { EVC } \\
(\%)\end{array}$ & $\begin{array}{l}h^{2} A \\
(\%)\end{array}$ & $\Delta \mathrm{g}$ & $\begin{array}{l}\Delta g \\
(\%)\end{array}$ \\
\hline FW $(g)$ & 3404.01 & 34.87 & 39.51 & 43.79 & 228.55 & 6.71 \\
\hline $\mathrm{FD}(\mathrm{mm})$ & 158.79 & 7.66 & 11.82 & 29.57 & 2.14 & 1.35 \\
\hline $\mathrm{FL}(\mathrm{mm})$ & 170.28 & 14.17 & 13.28 & 53.24 & 6.31 & 3.71 \\
\hline PT (mm) & 33.79 & 13.47 & 16.15 & 41.01 & 0.77 & 2.28 \\
\hline $\mathrm{BT}$ (mm) & 0.83 & 16.24 & 22.87 & 33.52 & 0.01 & 0.67 \\
\hline $\mathrm{FC}(\mathrm{mm})$ & 90.36 & 8.9 & 16.71 & 22.09 & 1.36 & 1.51 \\
\hline $\mathrm{PF}\left(\mathrm{kg} \mathrm{cm}^{-2}\right)$ & 4.01 & 20.44 & 32.69 & 28.12 & -0.06 & -1.46 \\
\hline $\mathrm{PA}(\mathrm{pH})$ & 6.62 & 4.71 & 5.63 & 41.17 & 0.05 & 0.71 \\
\hline SS ('Brix) & 7.24 & 11.57 & 12.39 & 46.59 & 0.32 & 4.44 \\
\hline$P\left(\mathrm{~kg} \mathrm{ha}^{-1}\right)$ & 7564.52 & 34.87 & 39.51 & 43.79 & 507.36 & 6.71 \\
\hline
\end{tabular}

GVC, genetic variation coefficient; EVC, environmental variation coefficient; $h^{2}{ }_{A}$, heritability in a broad sense, $\Delta g$, expected genetic progress; $F D$, fruit diameter; $F L$, fruit length; CT, cortex thickness; PT, pulp thickness; FC, fruit cavity; SS, soluble solids; PA, pulp acidity; PF, pulp firmness; P, production (kg ha-1).

The wide-ranging heritability estimates had a moderate magnitude (30-60\%) for all the evaluated characteristics, except for fruit diameter (FD), fruit cavity (FC) and pulp firmness (PF), which had a low magnitude $(<30 \%)$, indicating that environmental variance plays an important role in the manifestation of the phenotypic variance of the evaluated characteristics. These estimates differ from those found by Reddy et al. (2013b), who reported high heritability values for fruit length (83.92\%), average fruit weight $(90.35 \%)$, length of fruit cavity $(89.41 \%)$, width of the fruit cavity (66.93\%), bark thickness $(70.39 \%)$ and total soluble solids (86.51\%). Rakhi and Rajamony (2005) reported high heritability for fruit length, fruit circumference, average fruit weight, and production per plant, which meant that the variability of these characteristics had a high percentage because of genetic variation with greater correspondence between the phenotypes and the genotype. Reddy et al. (2013) found high heritability for the production in melon, which implied that this characteristic can be improved through selection.

The estimated values of genetic progress had a low magnitude $(<10 \%)$ in all the evaluated characteristics because of the moderate or low heritability. Reddy et al. (2013) reported different genetic progress for all the characteristics, with the exception of fruit weight and length. The estimates of genetic advance had a high great magnitude (> 20\%) for average fruit weight (57.27\%), bark thickness (49.04\%), total soluble solids $(24.68 \%)$, and fruit production (30.50\%) and a moderate magnitude (10-20\%) for the fruit length $(17.21 \%)$, fruit diameter $(10.02 \%)$ and pulp thickness (13.51\%).

Although the heritability was moderate for fruit weight (FW), soluble solids (SS) and production (kg $\mathrm{ha}^{-1}$ ), the genetic advance was significant taking into account the agronomic and economic importance of these characteristics (Rakhi and Rajamony, 2005). In general, selection for melon types with high production and quality should focus on average fruit weight, production per hectare and content of soluble solids.

\section{CONCLUSIONS}

Moderate genetic variability was found in all the characteristics evaluated in the 20 half-sib families of the creole melon; therefore, there are possibilities for improving these characteristics through recurrent selection. All the families were superior to the control treatment in 7 of the 10 fruit characteristics. Family 93 stood out for fruit weight and production (kg ha ${ }^{1}$ ), and family 196 did so for total soluble solids. Heritability broadly had a moderate magnitude for all the analyzed characteristics. The genetic progress had a low magnitude for most characteristics. In recurrent selection processes, the characteristics demanded by the market, mainly soluble solids and average fruit weight, must be considered. 
Conflict of interests: this manuscript was prepared and reviewed with the participation of all authors, who declare that there exists no conflict of interest that puts at risk the validity of the presented results.

\section{BIBLIOGRAPHIC REFERENCES}

Abraham, M.R., I. Espitia-Vázquez, R. Guzmán-Mendoza, V. Olalde-Portugal, G.M.L. Ruiz-Aguilar, J.L. García-Hernández, L. Herrera-Isidrón, and H.G. Núñez-Palenius. 2018. Development, yield, and quality of melon fruit (Cucumis melo L.) inoculated with mexican native strains of Bacillus subtilis (Ehrenberg). Agrociencia 52(1), 91-102.

Aragão, F.A., G.H. Souza Nunes, and M.A. Queiróz. 2015. Genotype $\mathrm{x}$ environment interaction of melon families based on fruit quality traits. Crop Breed. Appl. Biotechnol. 15(2), 79-86. Doi: 10.1590/1984-70332015v15n2a15

Chacón, X. and M. García. 2016. Redes de custodios y guardianes de semillas y casas comunitarias de semillas nativas y criollas. Guía metodológica. Edición SWISSAID; Corporación Biocomercio Sostenible, Bogota.

Eguiarte, L.E., J.A. Aguirre-Liguori, L. Jardón-Barbolla, E. Aguirre-Planter, and V. Souza. 2013. Genómica de poblaciones: nada en evolución va a tener sentido si no es a la luz de la genómica, y nada en genómica tendrá sentido si no es a la luz de la evolución. TIP Rev. Esp. Cienc. Quím. Biol. 16(1), 42-56. Doi: 10.1016/ S1405-888X(13)72077-1

FAO. 2014. Anuario Estadístico de la FAO: la Alimentación y la Agricultura en América Latina y el Caribe. Santiago: Oficina Regional de la FAO para América Latina y el Caribe, Santiago.

FAO. 2018. FAOSTAT - Crop. In: http://www.fao.org/ faostat/en/\#data/QC; consulted: March, 2018.

GADCO, Gobierno Autónomo Descentralizado del Cantón Quevedo. 2014. Plan de desarrollo y de ordenamieto territorial. Quevedo, Ecuador.

Guis, M., J.P. Roustan, C. Dogimont, M. Pitrat, and J.C. Pech. 1998. Melon biotechnology. Biotechnol. Genet. Eng. Rev. 15(1), 289-312.

INAMHI, Instituto Nacional de Meteorología e Hidrología de Ecuador. 2016. Boletín climático semestral. Quito.

Latrasse, D., N.Y. Rodriguez-Granados, A. Veluchamy, K.G. Mariappan, C. Bevilacqua, N. Crapart, C. Camps, V. Sommard, C. Raynaud, C. Dogimont, A. Boualem, M. Benhamed, and A. Bendahmane. 2017. The quest for epigenetic regulation underlying unisexual flower development in Cucumis melo. Epigenet. Chromatin 10, 22. Doi: 10.1186/s13072-017-0132-6
Monge, J.E. 2016. Evaluación de 70 genotipos de melón (Cucumis melo L.) cultivados bajo invernadero en Costa Rica. InterSedes 17(36). Doi: 10.15517/isucr. v17i36.26944

Monge-Pérez, J.E. 2013. Producción y exportación de melón (Cucumis melo) en Costa Rica. Tecnol. Marcha 27(1), 93-103. Doi: 10.18845/tm.v27i1.1700

Pavan, S., A.R. Marcotrigiano, E. Ciani, R. Mazzeo, V. Zonno, V. Ruggieri, C. Lotti, and L. Ricciardi. 2017. Genotyping-by-sequencing of a melon (Cucumis melo L.) germplasm collection from a secondary center of diversity highlights patterns of genetic variation and genomic features of different gene pools. BMC Genomics 18, 59. Doi: 10.1186/s12864-016-3429-0

Pistorale, S.M., L.A. Abbott, and A. Andrés. 2008. Diversidad genética y heredabilidad en sentido amplio en agropiro alargado, Thinopyrum ponticum. Cien. Inv. Agr. 35(3), 259-264. Doi: 10.4067/S0718-16202008000300003

Pitrat, M. 2008. Melon. pp. 283-315. In: Prohens, J. and F. Nuez (eds.). Handbook of plant breeding. Vol 1: vegetables I. Springer, New York, NY. Doi: 10.1007/978-0-387-30443-4_9

Rakhi, R. and L. Rajamony. 2005. Short communication Variability, heritability and genetic advance in landraces of culinary melon (Cucumis melo L .). J. Trop. Agric. 43(1-2), 79-82.

Reddy, B.P.K., H. Begum, N. Sunil, and M.T. Reddy. 2013a. Variance component analysis of quantitative traits in muskmelon (Cucumis melo L.). Trakia J. Sci. 11(2), 118-124.

Reddy, B.P.K., H. Begum, N. Sunil, M.T. Reddy, J.D. Babu, and R.S.K. Reddy. 2013b. Correlation and path coefficient analysis in muskmelon (Cucumis melo L.). Suranaree J. Sci. Technol. 20(2), 135-149.

Sebastian, P., H. Schaefer, I.R.H. Telford, and S.S. Renner. 2010. Cucumber (Cucumis sativus) and melon (C. melo) have numerous wild relatives in Asia and Australia, and the sister species of melon is from Australia. Proc. Natl. Acad. Sci. USA 107(32), 14269-14273. Doi: 10.1073/pnas. 1005338107

UPOV, Unión Internacional para la Protección de las Obtenciones Vegetales. 2008. Adenda del documento C/41/12 Add. Ginebra. In: http://www.upov.int/ edocs/mdocs/upov/es/c/41/c_41_12_add.pdf; consulted: October, 2017.

Wang, Y.-H., D.-H. Wu, J.-H. Huang, S.-J. Tsao, K.-K. Hwu, and H.-F. Lo. 2016. Mapping quantitative trait loci for fruit traits and powdery mildew resistance in melon (Cucumis melo). Bot. Stud. 57, 19. Doi: 10.1186/ s40529-016-0130-1 